\title{
Editorial
}

\section{Liver Transplantation in Pediatrics}

\author{
Yasuhiko Sugawara *
}

Department of Transplantation/ Pediatric Surgery, Postgraduate School of Life Science, Kumamoto University, 1-1-1 Honjo, Chuo-ku, Kumamoto 8603-8556, Japan; E-Mail: yasusuga-tky@umin.ac.jp

* Correspondence: Yasuhiko Sugawara; E-Mail: yasusuga-tky@umin.ac.jp

Special Issue: Pediatric Liver Transplantation

OBM Transplantation

2020, volume 4, issue 2

doi:10.21926/obm.transplant.2002111
Received: May 15, 2020

Accepted: May 15, 2020

Published: May 18, 2020

\section{Keywords}

Liver transplantation; living donor; hepatocellular carcinoma

Since the first case, which was indicated for biliary atresia by Starzl in 1967, the pediatric liver transplantation has gradually developed so far. The 5-year survival rate is currently around $85-90 \%$ in well-established centers of pediatric liver transplantation [1].

Apparently, liver transplantation has now become the standard treatment for the children with chronic end-stage liver disease, tumors (hepatocellular carcinoma, hepatoblastoma), metabolic diseases, and acute liver failure [2]. The techniques to harvest and procure split-liver grafts from deceased or living donors have been refined. The availability of organs has increased, and the waitlist mortality of the patients has decreased. Around $90 \%$ of the patients on the waitlist now eventually undergo liver transplantation [1].

The postoperative care has been well optimized by the introduction of a multidisciplinary team consisting of transplant surgeons, pediatricians, pediatric transplant hepatologists, transplant coordinators, psychologists, and social workers [3]. The clinical efforts have shifted from preventing mortality to improving the morbidity with satisfactory postoperative outcome. It is important to tailor the immunosuppressive drugs to prevent acute or chronic cellular rejection or antibody-mediated rejection. It can also contribute to avoiding infection and posttransplant

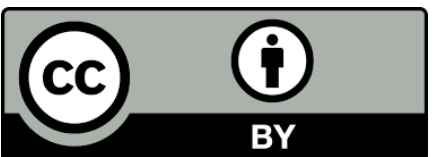

(C) 2020 by the author. This is an open access article distributed under the conditions of the Creative Commons by Attribution License, which permits unrestricted use, distribution, and reproduction in any medium or format, provided the original work is correctly cited. 
lymphoproliferative disease. The patients must be closely followed up, and the liver enzymes, function, and immunosuppressive drug levels should be monitored. Adherence to the medication is sometimes challenging in adolescents and young adults, and at the same time, nonadherence results in rejection and graft loss.

An interesting issue is that some children can be introduced to the operational tolerance. According to the multicenter trials on the withdrawal of the immunosuppressive drugs, a successful tolerance rate of approximately $60 \%$, in the selected recipients based on a biochemical and histological basis, was observed [4].

\section{Author Contributions}

YS proposed the study and wrote the draft.

\section{Funding}

No benefits in any form have been received or will be received from a commercial party related directly or indirectly to the subject of this article.

\section{Competing Interests}

The author declared no conflict of interest.

\section{References}

1. Cuenca AG, Kim HB, Vakili K. Pediatric liver transplantation. Semin Pediatr Surg. 2017; 26: 217-223.

2. Pham YH, Miloh T. Liver Transplantation in Children. Clin Liver Dis. 2018; 22: 807-821.

3. Spada M, Riva S, Maggiore G, Cintorino D, Gridelli B. Pediatric liver transplantation. World J Gastroenterol. 2009; 15: 648-674.

4. Feng S, Bucuvalas J. Tolerance after liver transplantation: Where are we? Liver Transpl. 2017; 23: 1601-1614. 


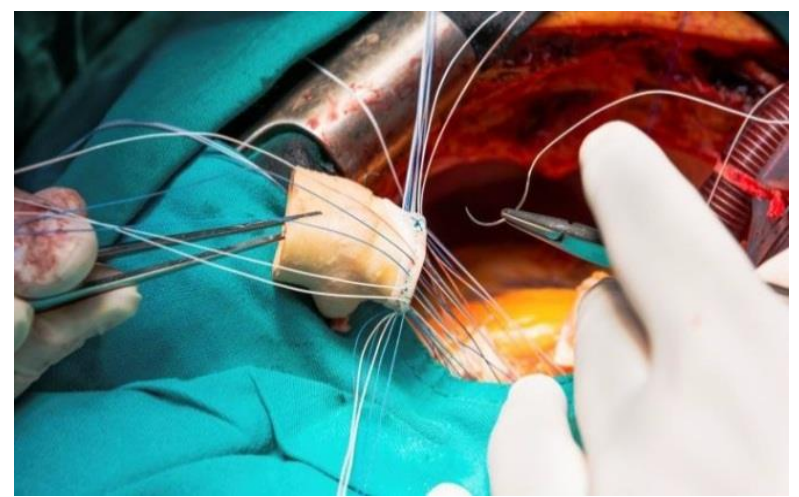

Enjoy OBM Transplantation by:

1. Submitting a manuscript

2. Joining in volunteer reviewer bank

3. Joining Editorial Board

4. Guest editing a special issue

For more details, please visit:

http://www.lidsen.com/journals/transplantation 